\title{
LUGARES QUE MIGRAM - AS IMAGENS DO MUNDO VIVIDO PELOS ASSENTADOS DO CANOAS/AM
}

\section{Places that migrate - The images of the world lived by the Canoas seated - AM.}

\author{
Diane Maria Oliveira Sacramenta \\ Mestre em Geografia pela Universidade Federal do Amazonas. \\ Professora da rede pública e privada de Ensino (SEMED-MANAUS/SEDUC-AM/FAMETRO-Manaus) \\ dsacramenta@gmail.com
}

Amélia Regina Batista Nogueira Professora do Departamento de Geografia e do Programa de Pós-Graduação em Geografia da Universidade Federal do Amazonas - UFAM. ab.nogueira@uol.com.br

RESUMO: O Canoas apresenta-se como Comunidade e Assentamento rural. Sua dinâmica pode se melhor compreendida considerando duas etapas, antes e após a chegada do Projeto de Assentamento (P.A.). Nesse sentido, o objetivo deste trabalho foi descrever e compreender como os migrantes assentados representam suas vivências e os lugares de seus trajetos, bem como o Canoas, criando com ele uma relação de identidade. Participaram da pesquisa dez colaboradores adultos, não naturais da região norte, devido às experiências adquiridas na migração, e três dos antigos habitantes do lugar, demonstrando a percepção sobre a chegada desses novos sujeitos. Os mapas mentais e a história oral nos auxiliaram no acesso ao mundo vivido de cada indivíduo. Trata-se de uma pesquisa qualitativa, na perspectiva fenomenológica da Geografia. Portanto, esta pesquisa contribui na compreensão da (re) construção do lugar nas multidimensionalidades do vivido, bem como, da relação de identidade existente, ou não, pois é a partir da manifestação das relações estabelecidas que o mesmo acontece.

Palavras-chave: Percepção, Representação, Lugar, Migração, Identidade.

\begin{abstract}
Canoas is a rural community and a settlement. Its dynamism might be better understood if we consider its two periods: before and after the settlement project (SP). Thus, we aim to describe and comprehend how settled migrants represent their way of life and paths taken, as well as Canoas, developing an identity relationship with it. Ten migrant subjects not from the North region participated in the research due to their background in the migration process. Three old inhabitants also participated in the research to describe their perception upon migrants' arrival. Mental maps and oral history help us understand each subjects' experience lived upon settlement. It is a qualitative research in phenomenological geography; therefore, it contributes to comprehending and rebuilding the past place in multidimensional views, as well as the relationship in the existing identity or not since it is in the displaying of the relationships that they occur.
\end{abstract}

Key words: Perception, Representation, Place, Migration, Identity.

REVISTA GEONORTE, V.9, N.31, p.116-136, 2018. 


\section{INTRODUÇÃO}

O lugar e seus habitantes formam uma totalidade, não há como separá-los, embora a dinamicidade de uma dada porção do espaço geográfico não dependa exclusivamente de seus atuais habitantes, e, estes também poderem mudar de lugar. É inacabado, assim como seus habitantes também o são. Independente, das condições sociais e culturais, eles se ressignificam, dentre outros aspectos, através da migração com a inserção de novos elementos que o caracterizam, demonstrando que os sujeitos não migram sozinhos.

De acordo com Silva (2005) e Souza (2007), 50\% dos moradores do Canoas são naturais de outros Estados brasileiros, destacando-se: paraenses, maranhenses e cearenses. Partindo desse pressuposto, o objetivo desta pesquisa é descrever e compreender como os migrantes assentados representam suas vivências, os lugares de seus trajetos e o Canoas, criando com eles uma relação de identidade. Pensar a representação do trajeto e do vivido nos lugares é pensar em conhecer e compreender melhor o mundo vivido de sujeitos cujas experiências são adquiridas ao longo desses percursos, por diversos lugares, nos quais há tanto a aquisição quanto o compartilhamento de práticas vivenciadas.

Assim, a pesquisa possibilitou uma melhor compreensão da reconstrução do lugar e - significado dos lugares vividos em cada trajeto, demonstrando aspectos fundamentais que proporcionam a compreensão e reconhecimento do Canoas, como espaço experienciado, por homens e mulheres que nele vivem. As imagens do mundo vivido destacam a dinamicidade do lugar, fruto das manifestações integradas dos sujeitos que o constituem, identificando-se com o mesmo. "EU" reconheço-me diante do "OUTRO", com o qual me identifico, ou não, conduzindo a uma relação de identidade, remetendo à ideia de pertencimento.

\section{MATERIAIS E MÉTODOS}

A elaboração e obtenção dos resultados desta pesquisa foram fundamentados no método fenomenológico. Os mapas mentais e as narrativas foram utilizados como procedimentos metodológicos. A abordagem e os procedimentos, citados, têm como ponto de partida os conhecimentos pré-científicos de cada indivíduo. Esse é compreendido como sujeito, que em conjunto com o pesquisador, torna-se, responsável pela construção do trabalho. Nogueira (2004, p. 209) ao abordar a discussão fenomenológica na geografia, afirma que "o homem enquanto sujeito que está no mundo [...] tem dele uma experiência de vida". Para a autora, a fenomenologia, além de fazer uma descrição minuciosa dos fenômenos pesquisados, busca também, estudar o mundo vivido valorizando todas as experiências concretas do homem com este mundo, resultando na experienciação.

As narrativas, de acordo com Meyhy (2005), na perspectiva da história oral de vida, valoriza as versões individuais das pessoas sobre os fenômenos. Cada depoimento para a história oral tem peso autônomo, ainda que seja explicado cultural e 
socialmente. Acrescenta que os entrevistados não são apenas meros informantes da pesquisa, eles colaboram para a elaboração do trabalho, desde o primeiro contato com a pré-entrevista até a formalização dos resultados, com a conferência das transcrições, por isso, são chamados de colaboradores.

Os mapas mentais, conforme Nogueira (2001), são abordados como representações gráficas que demonstram o vivido imediato, sendo construídos com informações subjetivas do espaço vivido, tratando-se de uma interpretação fenomenológica da realidade de cada habitante. Nesse sentido, Claval (2001), afirma ser o objetivo da geografia atual, compreender a maneira como as pessoas vivem sobre a terra, experienciam os lugares que habitam ou visitam, encontram indivíduos e grupos, dão um sentido a esses contatos e tentam modificar as realidades nas quais vivem.

A coleta das narrativas foi realizada tendo como base as técnicas utilizadas pela história oral de vida, sendo: a pré-entrevista, entrevista e a pós-entrevista. Concluídas as entrevistas, realizou-se a pós-entrevista, etapa da conferência das transcrições por cada entrevistado. A Transcrição é entendida como o processo da mudança do estágio da gravação oral para o código escrito. Ela pode ser literal ou não. É dividida em: transcrição, textualização e transcriação. Foi priorizada a transcriação, pois: "O que deve vir a público é um texto trabalhado no qual a interferência do autor seja clara, dirigida para a melhoria do texto". A transcriação se compromete a ser um texto recriado em sua plenitude. Tudo deve obedecer a acertos combinados com o colaborador, que legitima o texto no momento da conferência. Partindo do princípio de que existem diferenças entre a língua falada e a escrita, o mais importante na passagem de um discurso para o outro é o sentido (MEIHY. 2005, p. 182).

Os mapas mentais foram elaborados com ênfase nos elementos mais significativos para cada indivíduo e feito individualmente. Cada colaborador fez a representação gráfica de seu trajeto e do Canoas no momento da chegada e um atual. Apenas um habitante antigo contribuiu com as elaborações dos mapas mentais do P.A.. A última etapa do processo é caracterizada pela análise e interpretação dos dados, relacionando-os com as discussões teóricas e narrativas, na tentativa de perceber o sentido da migração na vivência dos mesmos, e do próprio Canoas.

A aplicação dos procedimentos viabilizou o trabalho de campo, com observação direta e realização de entrevistas semi-estruturadas na área de estudo, com dez migrantes assentados e três habitantes que viviam no lugar antes da criação do P.A.. Como critérios de inclusão para os colaboradores consideraram-se: Os chefes de família; Ser natural de outros estados brasileiros, exceto região norte (pela experiência obtida na migração); Três dos antigos habitantes do lugar (pelo conhecimento das transformações ocorridas antes e após a chegada do assentamento); Todos assentados pelo INCRA - Instituto nacional de Colonização e Reforma Agrária. Desta forma, o universo da pesquisa foi o mundo vivido dos migrantes assentados e de três dos antigos habitantes do Canoas em Presidente Figueiredo-Am.

Neste artigo, não são apresentados todos os mapas mentais elaborados e todas as narrativas, mas os que aqui foram disponibilizados dão conta de representar as diferentes percepções dos lugares vivenciados. Entretanto, a análise e interpretação do vivido na migração são apresentadas, considerando as informações descritas por todos os participantes da pesquisa. Pode-se afirmar, mediante o exposto, que os 


\section{紧}

mapas mentais na perspectiva fenomenológica e as narrativas dentro da história oral de vida como procedimentos, valorizaram as versões individuais sobre os fenômenos e conduziram à apreensão das imagens do mundo vivido de cada colaborador da pesquisa.

\section{RESULTADOS E DISCUSSÕES}

\section{Entre a migração e o lugar: a necessidade de estar}

Cada lugar tem sua especificidade, tanto nas características naturais, como culturais. Em alguns se sobressaem as paisagens rurais, em outros as urbanas. As pessoas o representam conforme suas experiências, que pode ser tanto individual quanto o resultado das relações sócio-culturais. O lugar é formado, a partir do momento em que há uma relação mais íntima da pessoa com o espaço. Quando as pessoas migram estão á procura de um lugar, até porque, como bem demonstra Dardel apud Relph $(1979$, p. 16) "nós podemos trocar de lugares, mudar, mas isso é ainda a procura de um lugar".

O migrante, não migra sozinho, leva consigo um conjunto de elementos que implicam na ressignificação do lugar de destino, apresentando uma dinamicidade própria. Essa dinamicidade acontece a partir da inserção de características sociais, culturais, econômicas e até mesmo ambientais, conferindo uma identidade que se modifica conforme a perda ou o ganho desses elementos. Vale ressaltar, que "a vivência do 'brasileiro' muda de região para região, seja devido à localização geográfica, condições climáticas ou econômicas. Cada uma dessas regiões tem sua história, o que determina diferenças na linguagem, hábitos, valores, crenças ou tradições" (OLIVEIRA, 2005, p. 164).

Em seu artigo sobre migração, Menezes (2007) busca compreendê-la realizando uma leitura da viagem interna que se opera no indivíduo quando ocorre o processo migratório. Para ele, quando o ser migra, a alma vai fazendo sua própria viagem com representações imagéticas na mente. Acrescenta que as consequências do deslocamento aparecem na consciência e na inconsciência do indivíduo. Este ao invés de voltar ao seu lugar de origem, faz uma restauração simbólica, construindo o templo que abrigará a alma da sua cidade interior. Nesses termos, compreende-se que os lugares, também, migram na consciência dos sujeitos que os reconstroem de maneira seletiva, considerando o que houve de mais significativo em cada trajeto.

Uma comparação pode ser feita entre os lugares do trajeto desses migrantes com os lugares de memória discutidos por Mello. O lugar da memória é o de origem ou de situações pretéritas com o qual há uma relação de identidade, esse não se esquece, permanece na memória, é transitório ou eterno (MELLO, 2001, p. 94). Além do lugar de origem, há aquele lugar que ficou marcado na vida do migrante, esse segue com ele para outros lugares. Para Tuan (1983) a atual identidade de um lugar é criada através do uso seletivo de elementos que constituem o passado dos sujeitos que o habitam. Ressalta ainda, que a história reconstituída não necessita ser real; precisa somente se assemelhar á realidade. Nesse sentido, a Geografia tem como objetivo, compreender a maneira como as pessoas vivenciam a experiência do lugar onde 
vivem, e daqueles que visitam ou atravessam quando viajam. "O problema não é somente explicar porque a terra muda de acordo com os lugares. É compreender por que as pessoas associam aos mesmos lugares sentimentos, atitudes e humores diferentes" (CLAVAL, 2001, p. 45). Cada pessoa é única, por isso nas relações estabelecidas no e com o lugar compartilham e assimilam experiências seletivas que fazem parte da história de cada um. E é através dessas vivências que o lugar é reconstruído.

O migrante quando não possui vínculo com o lugar de destino, seu sonho é o retorno. Ele pode ser percebido como um sujeito em busca de um lugar onde possa atender suas necessidades de sobrevivência. Alguns saem de seu lugar de origem na infância acompanhando os pais, outros na juventude em busca de trabalho, em muitos casos, mulheres acompanhando os maridos, e, também, há aqueles que migram porque querem conhecer o mundo, ser um geógrafo na prática. Há, ainda, os que por motivos estritamente subjetivos almejam conhecer determinado lugar, ou porque ouviram falar do mesmo através de outras pessoas, ou pela imagem que tem do mesmo.

Ele, o migrante, pode ter realizado um longo trajeto até chegar ao seu novo lugar, seja um assentamento rural, uma pequena ou grande cidade, ou mesmo outro país. Assim como pode ser um trajeto entre dois pontos, do lugar de infância para o lugar de destino. A maioria desloca-se em busca de melhorias de vida. Dos Assentados que migraram em busca de trabalho, demonstraram uma trajetória caracterizada pelo labor nas fazendas (colheitas de feijão, arroz, milho etc.), nos garimpos e nas áreas de exploração de minério. Ao analisar o trajeto, percebe-se que o mesmo não ocorre entre dois pontos como sugere a teoria neoclássica, e que, também, mesmo sendo os motivos individuais, não se trata da decisão de uma pessoa somente. Nesse caso, há relação do processo migratório na vida desses assentados com a teoria neomarxista. Becker (1997) demonstra que migrantes são todos aqueles indivíduos que seguem o movimento do capital sob a condição de força de trabalho assalariada, ou potencialmente assalariada e a migração é concebida como um processo social que pode ter longa duração, ou seja, ser por etapas.

Nos depoimentos dos nordestinos é evidente a vontade de conhecer o mundo. $\mathrm{O}$ migrante assentado 09 disse o seguinte: "ser migrante está no sangue do nordestino", o que foge à explicação da teoria neomarxista. Nesse sentido, não se pode ser taxativo e determinar que os sujeitos que buscam outros lugares, o fazem, apenas devido a fatores econômicos. É certo que muitos seguem esse processo, mas para alguns o deslocamento tem outro significado. Sair do lugar de origem traz um sentido de liberdade (Migrante Assentado 02). Ser livre, andar e conhecer, esse é o objetivo, até o momento em que há a necessidade de criar raízes, de sentir-se parte, incluso. A identidade de um indivíduo e do próprio lugar é dinâmica. O que nos conduz a pensar no processo e não no resultado, como o próprio Haesbaert (1999) chama atenção. O processo em que se desdobra a realidade vivenciada, pode ser compreendido como a identificação que se manifesta e conduz à relação de identidade entre os sujeitos e desses com o lugar.

Nas narrativas estão expressas as vivências carregadas de sentimentos, que transparecem desde a tranqüilidade e segurança que permeava a Santa Terezinha até a manifestação dos graves problemas socioambientais que hoje agravam o lugar. 
Para os antigos habitantes, o lugar era muito melhor antes da territorialização do P.A., mesmo com as dificuldades que enfrentavam no que diz respeito á educação, saúde e meios de transporte, mas acrescentam que os problemas sociais (prostituição, drogas, homicídios) existentes, nos dias de hoje, no Canoas não possuem relação alguma com o P.A., e sim com os que vieram para trabalhar nas movelarias/serrarias.

Os migrantes assentados ao chegarem, enxergam o Canoas como um espaço a ser desbravado e construído. Essa situação nos possibilita pensar a relação que Tuan (1983) faz entre lugar e espaço. Pois o que começa como espaço indiferenciado, transforma-se em lugar à proporção que o conhecemos melhor e o dotamos de valor. Mesmo mediante tantos problemas existentes, possuem uma relação afetiva com o lugar, e que por esse motivo defendem que seja necessário um olhar mais atento das autoridades para essas situações, demonstrando o processo de identificação que se manifesta com o Canoas. Assim, "A (re) construção imaginária da identidade envolve, portanto uma escolha, entre múltiplos eventos e lugares do passado, daqueles capazes de fazer sentido na atualidade" (HAESBAERT, 1999, p. 181. O autor ressalta que convivem novas e antigas formas de identificação no/com o território, o que para nossa pesquisa falamos da convivência de novas e antigas formas de identificação no/com o Lugar. E dessa maneira quando o novo e o já estabelecido se encontram o lugar se transforma. Como exemplo tem a intensificação das migrações, conduzindo ao mesmo tempo a uma proliferação de microespaços de identidade, segregados/segregadores, e a um entrecruzamento de traços culturais que produzem espaços híbridos, articuladores de novas identificações com o lugar.

As relações de identidade que se manifesta com os lugares, podem ser melhor compreendida através da identificação, referindo-se à dinamicidade das relações estabelecidas. Nesse processo cria-se vínculos, ou não, com os lugares, ou seja, uma relação de pertencimento. Conforme Relph apud Marandola Jr (2010), a essência e a identidade do lugar são as chaves para a compreensão de sua construção. Acrescenta que os sentidos ou significados podem mudar ou serem transferidos para outros objetos. E que, os três componentes que constituem a identidade do lugar, proposto por Relph, são compostos e não monolíticos, sendo que a "configuração física envolve tanto a natureza (Terra) quanto o ambiente construído, enquanto as atividades podem ser criativas ou destrutivas ou passivas, coletivas ou individuais. $E$ os significados possuem atribuições e significantes muito distintos e mutantes" (MARANDOLA JR, 2010, p. 3), considerando que as pessoas têm modos diferenciados de vivenciarem os lugares, e, simultaneamente certa dinamicidade que varia conforme a natureza do próprio lugar.

Nas relações estabelecidas criam-se vínculos com os lugares. E como bem descreve Bezerra Jr (2005), ao discutir a noção de pertencimento tendo como base um fragmento de Clarice Lispector, chamado "pertencer", o sentimento de pertencimento significa o vínculo que se cria com as pessoas, aos lugares e suas realizações, é sentir-se parte do mesmo, conduzindo a uma noção de inclusão. O migrante quando não possui vínculo com determinado lugar, seu sonho é o retorno. Mesmo sendo a relação de identidade resultado do processo de identificação, algo que está sempre por acontecer, inacabado. É nessa relação que os lugares são (re) construídos, apresentando através do tempo seu diferencial. Não há a intenção de afirmar que o 
Canoas é o Lugar almejado, pronto, e, que cessou o movimento. Até porque os indivíduos percebem o lugar de maneiras diferenciadas.

O Lugar acontece através de processos que o torna único, diferenciando-se até mesmo de lugares vizinhos. No caso do Canoas, essa questão é bem nítida. Para se ter uma ideia, pessoas que passam por lá, moradoras de outras vilas (Cristo Rei, Novo Rumo e Rumo Certo), percebem o Canoas como "esquisito" e "depreciativo". Essa é a percepção obtida por quem passa. Por outro lado, é o mundo vivido de homens, mulheres e crianças que o experienciam todos os dias, e, para a maioria desses, é o Lugar que pretendem continuar. Partindo do contexto exposto, como representar os lugares de uma trajetória migracional, marcada pelo deslocamento no espaço, por encontros e desencontros, pela realidade e pelos sonhos, apegos e desapegos, alegrias e tristezas? Como representar lugares carregados de significados, repletos de experiências agradáveis, ou não? Nesse sentido, busca-se compreender melhor as vivências no trajeto e o acontecer desse lugar chamado Canoas, através das narrativas e mapas mentais dos migrantes assentados, os colaboradores deste trabalho.

\section{As imagens do mundo vivido nos lugares da migração}

"andar, andar! Conhecer! meu negócio era conhecer! Porque a pessoa estuda geografia, mas é teoria. Mas se você estuda geografia e sabe que existe aquele lugar, se você for lá, você sabe que é certo, é verdade". (MIGRANTE ASSENTADO 09).

Devido a necessidade de visualizarmos a maneira como cada colaborador contribuiu pra a elaboração deste trabalho, passa-se para a transcrição das narrativas e leituras dos mapas mentais. O quadro abaixo identifica cada migrante de 01 a 10 (considerando a ordem das entrevistas), indicando o lugar de origem, o trajeto e o destino atual.

QUADRO 01: Trajeto dos Migrantes Assentados no P.A. Canoas que participaram da pesquisa.

\begin{tabular}{|c|c|c|c|}
\hline $\begin{array}{l}\text { Migrante } \\
\text { Assentado }\end{array}$ & Origem & Trajeto & Destino atual \\
\hline 01 & $\mathrm{PI}$ & MA, GO, PA e AM & \multirow{10}{*}{$\begin{array}{l}\text { PROJETO } \\
\text { ASSENTAMENTO CANOAS/ } \\
\text { PRESIDENTE FIGUEIREDO- } \\
\text { AM. }\end{array}$} \\
\hline 02 & $\mathrm{SP}$ & MT, MS RO e AM & \\
\hline 03 & $\mathrm{PI}$ & $\mathrm{AM}, \mathrm{PI}, \mathrm{DF}, \mathrm{PI}, \mathrm{AM}$ & \\
\hline 04 & $\mathrm{RN}$ & PA e AM & \\
\hline 05 & MA & MA e AM & \\
\hline 06 & MA & MA e AM & \\
\hline 07 & BA & $\begin{array}{l}\text { PA, RO, PA, RR, PA, RR, PA, AM, } \\
\text { PA e AM }\end{array}$ & \\
\hline 08 & PR & RO, PR, RO, AM, RR e AM & \\
\hline 09 & CE & $\mathrm{AM}, \mathrm{RO}, \mathrm{PA}, \mathrm{RR}$ e $\mathrm{AM}$ & \\
\hline 10 & PR & PA e AM & \\
\hline
\end{tabular}

Fonte: Trabalho de Campo, julho/2009; abril/2010. 


\section{Migrante Assentado 01}

Sai numa caravana de pessoas do Sertão do Piauí em 29 de julho de 1979, de lá do meu interiorzinho, interior do Piauí, lugar chamado Mulato. Em 1980 e 1981, eu como muitos garimpeiros, muitos nordestinos, fiquei correndo atrás dos sonhos, com aquela intenção de melhorar de vida nos garimpos, e, nessa brincadeira de garimpo perambulei durante dez anos pelo Pará, Mato Grosso, Amazonas, Roraima, Guiana Inglesa e Rondônia em busca de riqueza. Depois de toda essa experiência, sendo de origem humilde, origem de agricultor, depois de dez anos sofrendo, pegando malária nos garimpos, fui sentindo que o homem vai amadurecendo e precisa por o pé no chão. Devido minha origem, tinha aquela grande vontade de ter um pedaço de terra para trabalhar. Cheguei pela primeira vez em Manaus em 1987, mas voltei. Ainda estava circulando na ilusão dos garimpos. Quando foi em 1989 cheguei outra vez em Manaus. E pensei: quero me casar com uma amazonense pra não ir mais embora daqui. Porque essa terra aqui é uma terra muito boa, aqui tudo o que se planta, produz: maxixe, macaxeira, melancia. Tudo que se produz, Manaus consome. Casei-me, trabalhava em Manaus, mas tinha aquele sonho de ter meu próprio pedaço de terra. Em 1996, conheci o Assentamento Canoas, em 1997, mudei-me para cá e fui assentado em 1998. Eu fui assentado em 1998 pelo INCRA, já tenho doze anos aqui, foi meu primeiro pedaço de terra, e aqui eu venho construindo meu sonho com muita dificuldade.

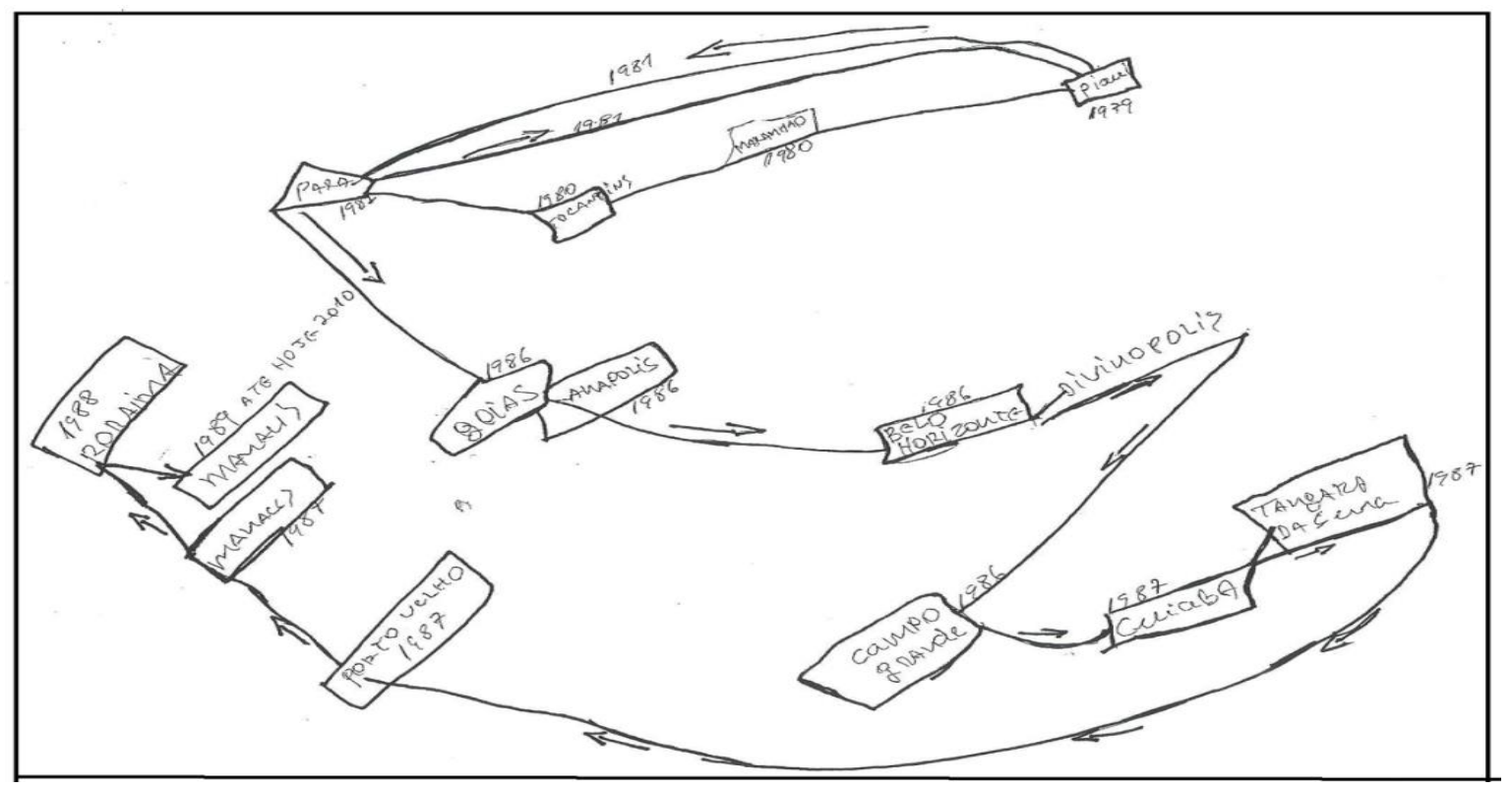

Figura 01: Trajeto/Mig. Assentado 01. Fonte: Trabalho de Campo, abril/2009. Migrante Assentado 02

Eu não me considero paulista. Eu considero paulista aqueles descendentes de imigrantes que vieram de fora, japoneses, italianos, esses receberam muito apoio. Os filhos desses vivem bem. Agora os descendentes de nordestinos, não. Então muita gente acha que para ser paulista basta nascer lá, eu não penso assim. Eu nasci lá, mas não sou paulista. Meu pai é baiano e minha mãe pernambucana, então eu não sou paulista. Caetano Veloso chama os filhos de nordestinos que nascem lá de novos baianos, ele não chama de paulista, e essa também é minha visão. Em São Paulo, 


\section{造}

você tem muito trabalho. Você começa sete horas da manhã e sai dezessete horas da tarde. Você praticamente não vive, você vegeta, e eu não nasci para ser um vegetal, eu nasci para ser livre. Tudo isso me sufocava, e eu queria ver se existia essa liberdade. Eu via através da televisão aqueles documentários da Amazônia, como viviam as pessoas. E eu tinha desejo de ver como era isso. De fazer parte desse povo. Então isso ficou sufocado porque meu pai era um pouco rígido. Ele me deu a liberdade quando eu tinha 25 anos de idade. A cidade que tinha ficado no meu coração, não era São Paulo, não era Porto Velho, não era lugar nenhum, era Presidente FigueiredoAM. A cidade que Deus falou para eu ir pregar o evangelho foi Presidente Figueiredo.

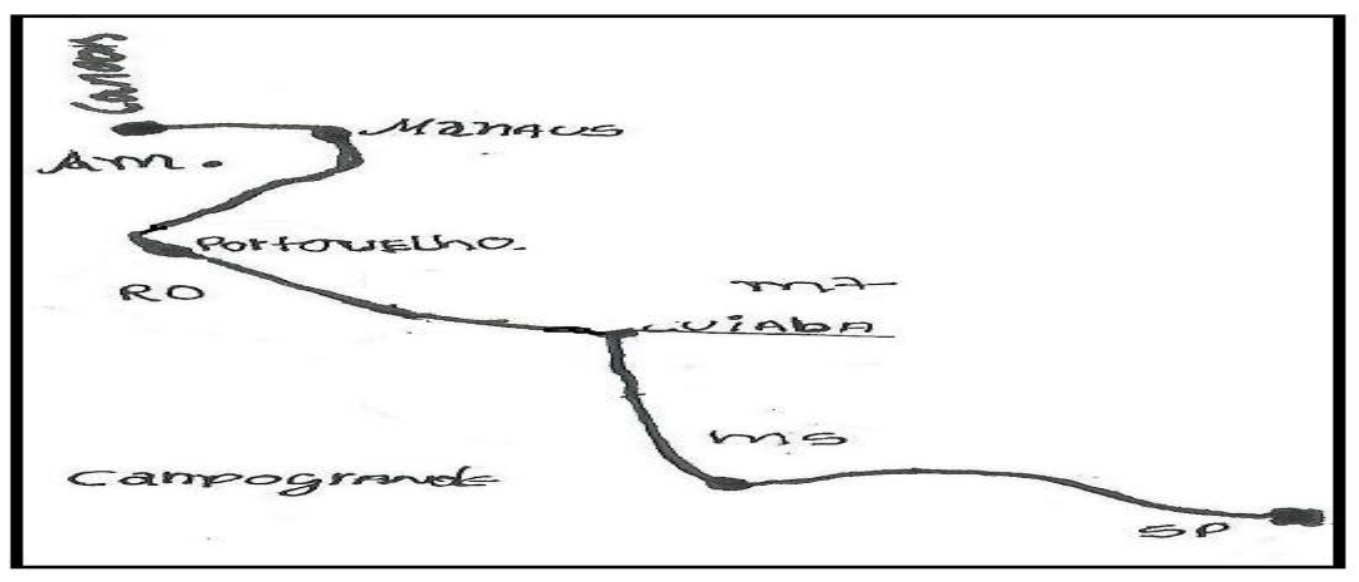

Figura 02: Trajeto Migrante Assentado 02. Fonte: Trabalho de Campo, abril/2009.

\section{Migrante Assentado 06}

O migrante assentado 06 é esposo da migrante assentada 05, ambos maranhenses. Saíram juntos do Maranhão para o Amazonas, vieram para Manaus, motivados por promessas de melhores condições de vida. Nasceram, cresceram e casaram-se no mesmo município. Fizeram os mesmos trajetos no Maranhão. Apresentamos apenas o depoimento dele, por abranger as vivências da unidade familiar.

Com tantas promessas de melhoria de vida, decidi deixar o meu lugar. Eu estava bem no Maranhão, não tinha terra, mas trabalhava numa fazenda e o meu patrão era muito bom pra mim. Eu já tinha gado, estava bem mesmo. Por isso, nos organizamos e vim com a família para Manaus. Dia vinte de dezembro de 1997 viemos para a cidade de Viturino Freire/MA. No dia vinte e três, embarcamos para Santa Inês/MA, onde tem a rodoviária que passa ônibus para São Luiz, Imperatriz, Brasília, para vários lugares. Ainda no dia vinte e três, às vinte e uma hora, pegamos ônibus para Belém. Chegamos em Belém no dia vinte e quatro, as cinco horas da manhã. A noite toda de viagem. Da rodoviária de Belém fomos para o navio. Chegamos em Manaus no dia trinta de dezembro de 1997, fomos morar na casa do meu avô no bairro da compensa. O impacto foi imediato. Comecei a ficar triste. Porque você é acostumado com uma coisa, chega à casa dos outros, você acha meio estranho. Minha mãe ficou alegre, os parentes todos vieram nos visitar, mas quando chegavam que viam um monte de menino, bom! acho que não gostaram. Mediante a situação, meu avô disse o seguinte: "meu filho, não tenho nada para te dar. O que tenho é uma casinha velha no fundo desse quintal, tu te viras aí". Os meus tios prometeram mil e uma coisas, quando 
cheguei, nada. Disseram que emprego era muito fácil, mas é fácil para quem tem estudo. Eu não estudei. A mulher entrou em depressão. No Maranhão, eu trabalhava em fazenda. Em Manaus, fui vender picolé. Eu ia para aquelas construções, oferecia o picolé e já pedia trabalho, contava a minha história: "sou do nordeste, estou aqui no Amazonas para ganhar a vida, estou vendendo esse picolé, mas meu ramo não é esse, não. Meu ramo é no pesado". Aí os caras te olha todos desconfiados, pensam que você é bandido, não davam trabalho para mim. Eu ficava pensando: meu Deus o que é que eu vim fazer aqui neste lugar? Aí foi, que eu vi onde estava. Rapaz, passava um filme na minha cabeça: mostrava o que eu tinha antes e o que eu não tinha naquele momento. Em junho de 1998, minha mulher ganhou neném. Ela já estava gestante quando saímos de lá. Eu estava numa crise muito feia. Crise mesmo. A mulher chorava, adoeceu todo mundo. A mulher pegou pneumonia, os meninos adoeceram, ficou uma coisa feia. O lugar onde agente morava era muito inconveniente, não tinha ar, os meninos viviam presos. Eu acho que eles não se deram bem com o lugar. Só que eu não desisti, vendi picolé, segui para a venda de verduras e farinha até que surgiu a oportunidade de conhecer o Canoas através de um tio. As informações eram de que o Canoas era muito bom, então decidi vim dar uma olhada, e, ele perguntou se eu não queria vim mais ele, dizendo: "Eu vou consegui um terreno lá. E se eu conseguir tu vais tomar conta para mim?". Eu já estava com oito meses em Manaus e doido para sair de lá. Eu dizia, "meu Deus, eu não quero ficar nesse lugar. Aqui não é lugar para mim. Eu não tenho estudo. Quero ir embora daqui, eu gosto é do mato". Aí a mim me animou, e respondi: "vou mesmo!". 


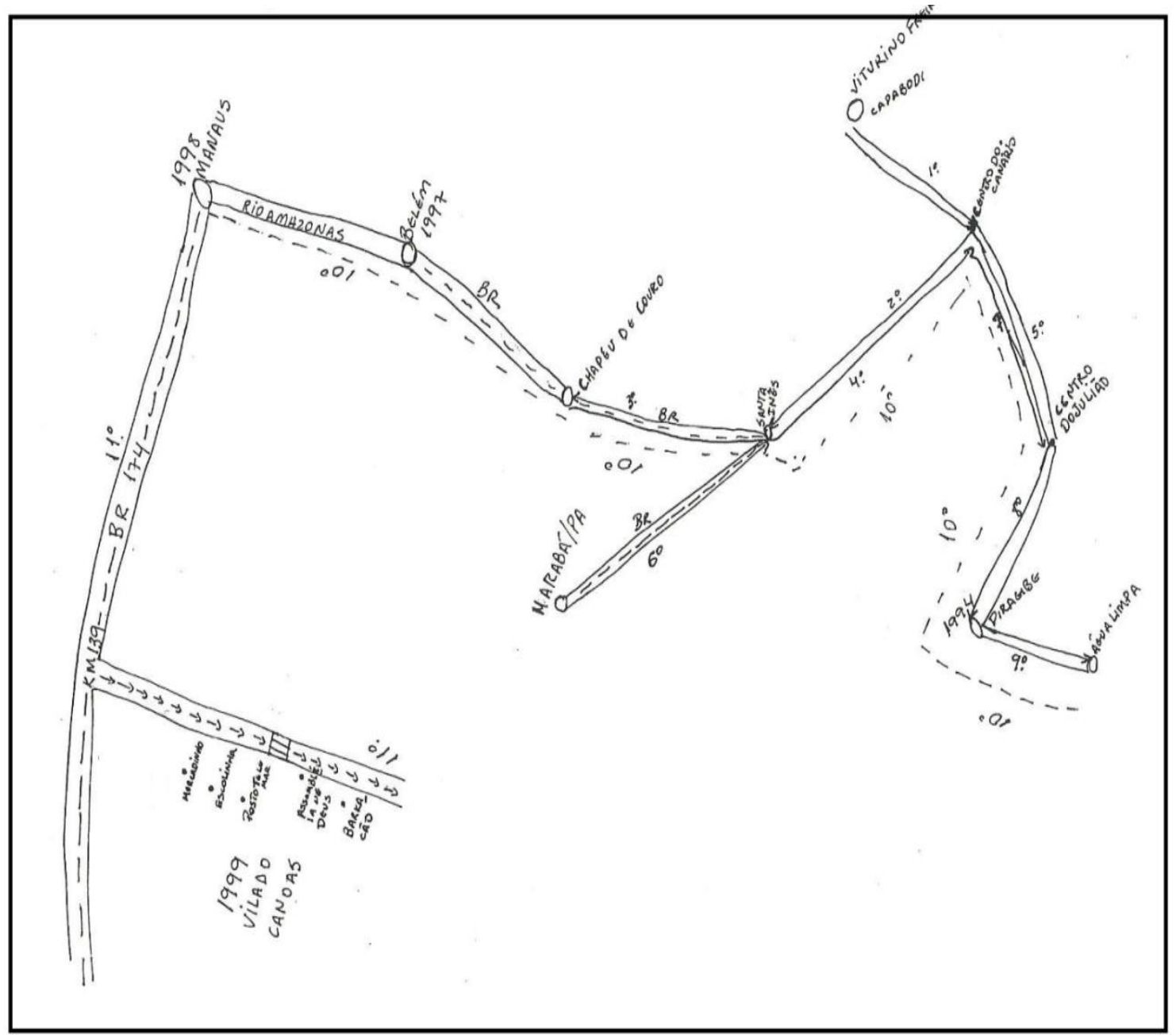

Figura 03: Trajeto Migrante Assentado 06. Fonte: Trabalho de Campo, abril/2010.

\section{Sobre as narrativas e os mapas mentais do trajeto do trajeto}

Conforme o trajeto realizado por cada sujeito da pesquisa, percebemos de imediato uma migração por etapas, com exceção de dois que vieram do Maranhão diretamente para o Amazonas (Migrantes Assentados 05 e 06), sendo que o lugar de destino era Manaus e não o Canoas. Mediante as dificuldades vivenciadas no espaço urbano, em que não havia uma relação que possibilitasse o estabelecimento de um vínculo com o lugar, a alternativa era a busca, o encontro consigo mesmo, com suas origens. Mesmo esses sujeitos tendo realizado um trajeto diretamente do Maranhão para o Amazonas, isto não significa que esse tenha sido o único percurso realizado, até porque antes de migrar de seu Estado de origem, deslocavam-se entre os lugares vizinhos até tomarem a decisão de partir para outro Estado brasileiro.

Dos dez colaboradores, oito realizaram uma longa trajetória até chegarem ao assentamento. A maioria saiu no período da juventude de sua terra natal, outros na infância, acompanhando os pais. Os motivos ou fatores de repulsão: Melhoria de vida e o sonho de ter a propriedade da terra. Quanto aos fatores de repulsão, Singer (1998) os classifica de duas ordens: fatores de mudança e de estagnação. Os de mudança 
dizem respeito à inserção das relações de produção capitalistas no campo que expropria e expulsa o camponês. Os de estagnação são caracterizados tanto pela insuficiência de áreas cultiváveis como pela atuação dos latifúndios.

Portanto, as questões políticas, econômicas e subjetivas envolvem-se nos depoimentos. Para alguns o desejo é mudar de rumo. Mudar de rumo significa buscar outros meios de sobrevivência. Mas a relação estabelecida com a terra, desde a infância, no trabalho realizado com o pai, os fazem pensar em retornar para o mesmo rumo, para a agricultura. Outro ponto que chama atenção é o lugar de origem como ponto de referência para alguns, outros não o mencionam, destacando, apenas, os lugares da infância. Evidenciando, que o lugar é construído a partir das relações que se manifestam em determinada porção do espaço geográfico, podendo mudar, ou não, conforme as dinâmicas estabelecidas.

\section{Entre a topofilia e a topofobia: um lugar chamado Canoas}

O Projeto de Assentamento Canoas está localizado no Km 139, margem esquerda da BR-174 no Município de Presidente Figueiredo-AM (figura 04 ), distanciando-se 139 Km em linha reta de Manaus. Implantado em 1992 pelo Instituto Nacional de Reforma Agrária (INCRA), atualmente é formado por quatro comunidades: Santa Terezinha e Canoas com acesso pelo ramal do Canoas no Km 139; a Comunidade Bom Jesus no ramal Novo Progresso e a Santa Terezinha II, com acesso pelo ramal do Urubuí II no Km 126. Com 262 famílias assentadas (INCRA, 2009).

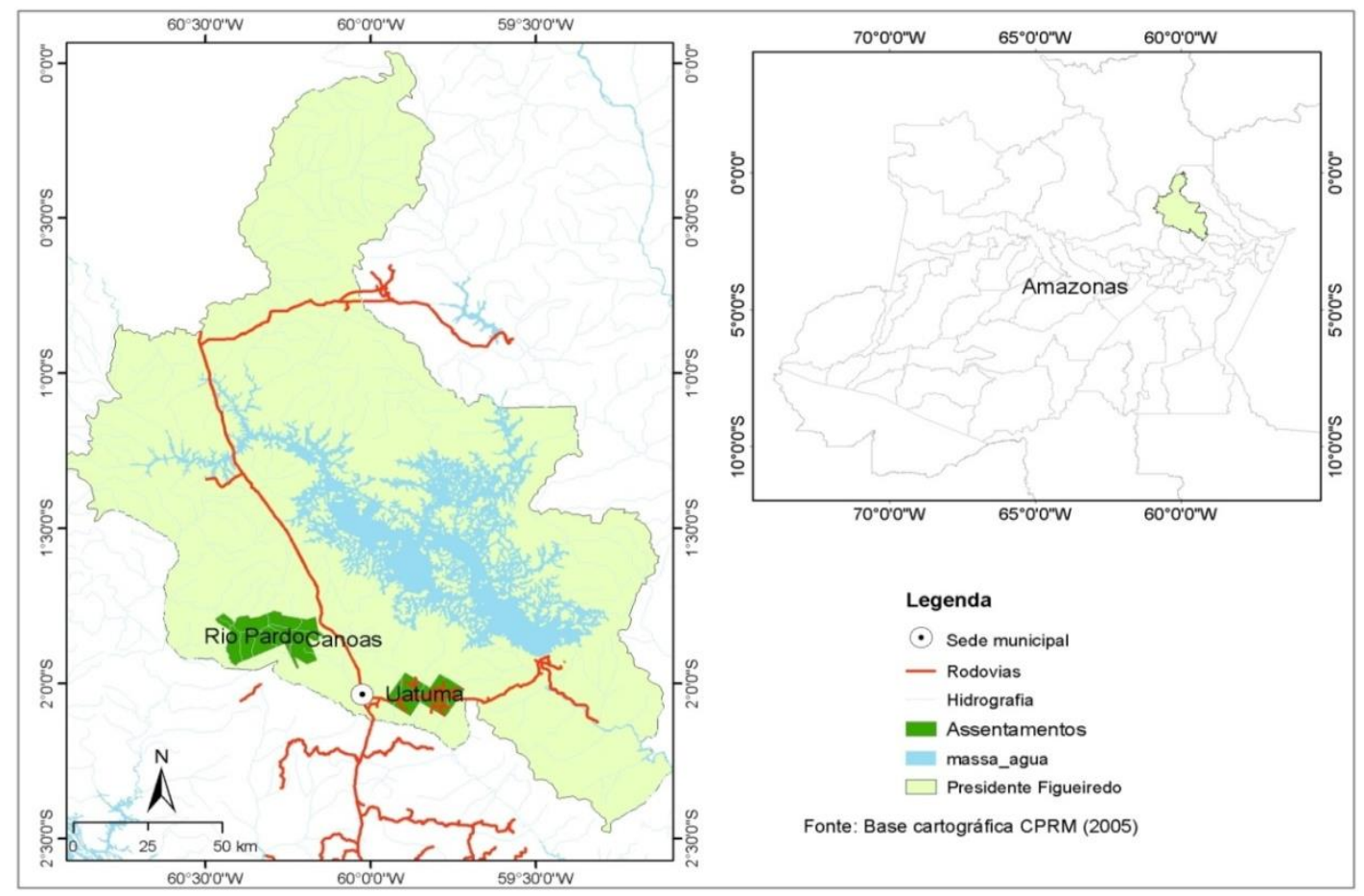

Figura 04: Localização Geográfica de Presidente Figueiredo-AM.

Fonte: Base Cartográfica CPRM, 2005. Org. Eduardo Pinheiro, 2009. 


\section{紧}

Chega-se ao Canoas pelo ramal do Canoas - Km-139 da BR 174. Após $07 \mathrm{Km}$ de ramal avista-se a "Associação Comunitária Santa Terezinha" ou "Vila do Canoas", como é popularmente conhecida.

Casas de alvenaria, umas poucas, a maioria é de madeira, igrejas, bares, mercearias (mercadinhos) e movelarias se entremeiam e juntamente com outros elementos da paisagem como a fiação que possibilita a chegada da energia elétrica e as antenas parabólicas, conduzindo o mundo para dentro dos lares, através da televisão, os telefones públicos para receberem e darem notícias de outros lugares, são características da vila do Canoas.

Ao se afastar da vila em direção aos lotes, as moradias se distanciam, mas em alguns trechos há a manifestação de algumas comunidades, como é o caso da Comunidade Bom Jesus, no ramal Novo Progresso. Escolas municipais de ensino fundamental, Igrejas evangélicas e algumas mercearias se manifestam ao longo do percurso. A marca mais significativa da paisagem é a vegetação, caracterizada pela floresta e por algumas áreas de pastagens, além das palmeiras de côco, cultivados pelos agricultores e outras que são nativas: buritizais e açaizeiros. Como paisagem de fundo, a exuberância das castanheiras. Atividades de plasticultura (técnica moderna de se cultivar hortaliças), a piscicultura (criação de peixes em tanques), e, até mesmo floricultura (cultivo de flores). A produção de côco e cupuaçu são as que predominam. Entretanto, há também o cultivo da banana, macaxeira, pupunha, e, alguns falam até mesmo em feijão, arroz e milho, esses somente para a subsistência. Outra característica é a presença dos madeireiros e o latifúndio que se territorializam. Devese lembrar da precariedade dos ramais, principalmente, no Ramal do Urubui I, o que se deve à ausência de pavimentação, bem como às características naturais do relevo acidentado. As condições se agravam em dias chuvosos, quando fica praticamente intrafegável.

Até aqui foi apresentado o Canoas conforme as observações feitas no trabalho de campo. Nas páginas que seguem, ele será visto através do olhar dos habitantes que o vivenciam, possibilitando-o suas especificidades.

\section{Percepção e representação do canoas}

\section{A Comunidade Santa Terezinha}

A colaboradora ZG, amazonense, primeira a ser entrevistada, é identificada como habitante 01 e o segundo, habitante 02 . Em suas narrativas contribuíram para uma melhor compreensão do processo de formação do lugar, bem como da dinamicidade local. O habitante 02, além da narrativa elaborou dois mapas mentais, antes e após a criação do P.A. Foram identificados como habitantes, pois,

\footnotetext{
Habitar implica mais do que morar, cultivar ou organizar o espaço. Significa viver de um modo pelo qual se está adaptado aos ritmos da natureza, ver a vida da pessoa como apoiada na história humana e direcionada para um futuro, construir um lar que é o símbolo de um diálogo diário com o meio ambiente ecológico e social da pessoa (BUTTIMER, 1985, p. 166).
} 


\section{Habitante 01}

Aqui já moro há 31 anos. Cheguei em março de 1978. Já era Canoas. Até porque conforme as histórias contadas pelos moradores daqui, esse nome foi dado pelos indígenas. Contavam que um índigena deixou uma canoa abandonada aí no rio, que também tem o nome de Canoas. A canoa se tornou um ponto de referência. Então batizaram esse lugar com o nome de Canoas. Quando cheguei aqui havia apenas dois habitantes, o Lucy e o Severino, os dois já faleceram. Não tinha estrada, não tinha nada, era por uma trilhazinha que caminhávamos. As pessoas vinham, gostavam e ficavam. Tudo o que se plantava, dava: banana, macaxeira [...], havia muita produção. Esta era escoada até a BR com a utilização de um jerico. Da BR era embarcado para a sede de Presidente Figueiredo ou para Manaus. Nós organizávamos mutirões, hoje em dia ninguém quer mais se organizar para trabalhar assim, consideram perda de tempo. Daí começou o fracasso da produção, que hoje é pouquíssima. Saíam daqui de dez caminhões lotados de produtos, depois foi diminuindo para quatro, três. Depois veio a Escola do Mobral, no início com dez alunos. A construção da sede da comunidade foi feita pelos próprios moradores. Já haviam aproximadamente trinta famílias, uns chegavam, gostavam e iam ficando, outros voltavam. Organizávamos torneios e muitas reuniões, reunião grande, reunião boa mesmo, mas isso antes do assentamento. O Assentamento foi criado em 1992. Foi chegando gente de todo lado, do Maranhão, da Bahia, do Piauí, do Mato Grosso e do Pará. Chegou a "tal" da reforma agrária. Nós só fomos vendo miséria, só gente pobre. Hoje os produtos que se destacam são: côco, quando é tempo de pupunha, sai pupunha, alguns tem macaxeira; ninguém ver mais milho, feijão verde; a banana também diminuiu. A terra parece que cansou, não sei como foi, e há também a proibição para o desmatamento. Além disso, hoje tem muitas igrejas evangélicas, antes não, era só a católica. Agora não sei se o assentamento continua ou acaba.

\section{Habitante 02}

Cheguei nessa região em 1974, cultivava arroz, feijão, milho e melancia. Nessa época - Canoas não tinha nada, não tinha nem ramal. Nós e outros vizinhos fomos quem abrimos uma picada. Era um lugar isolado, com poucos moradores. Agente começou entrando para pescar e caçar. Aí fomos fazendo o caminho até chegar esse ponto (figura 05). Antigamente tinha muita caça e muito peixe. Cada família trabalhava para si. As festas eram animadas, mas eu não era um frequentador assíduo, porque não tinha tempo. Era tempo do corre-corre, tinha que trabalhar para sobreviver. A chegada do Assentamento vem acompanhada da abertura de ramais (figura 06), energia elétrica. Mas, com tudo isso veio a poluição dos igarapés, incluindo os problemas sociais: como as drogas e a criminalidade. Hoje trabalho com piscicultura, não pesco mais. Crio porcos e galinhas. Cultivo pimenta e banana, porque são os produtos que dão com mais facilidade. 


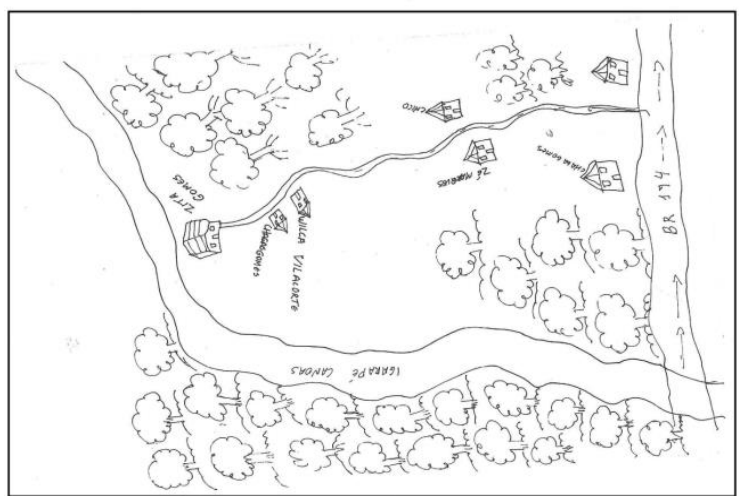

Fig.05: O Canoas antes da criação do P.A Fonte: Habitante 02, abril/2010.

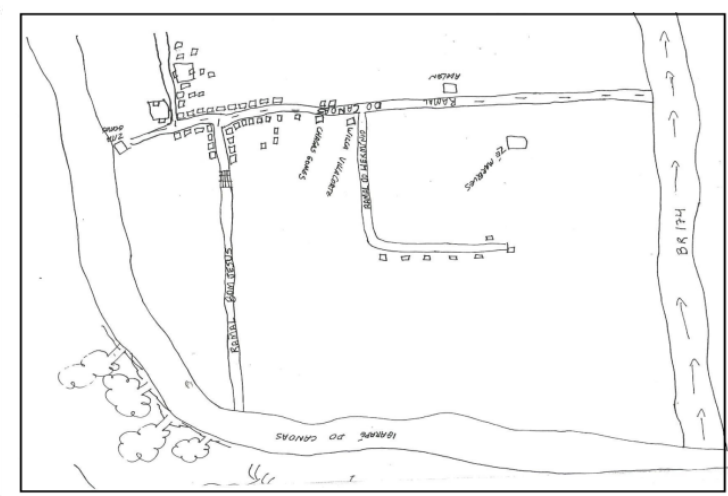

Fig. 06: O Canoas depois da criação do P.A. Fonte: Habitante 02, abril/2010.

\section{O Projeto de Assentamento: O lugar revelado}

\section{Migrante Assentado 01}

Em 1998 quando cheguei havia apenas 6,5 Km de ramal até a comunidade e mais 02 $\mathrm{Km}$ adentro (figura 07). Todo o Assentamento era assistido e trafegável por água, pelo rio Canoas. Havia muita produção de banana, macaxeira, farinha, cana e milho. Quase não tinha problemas com criminalidade. Mas o lugar era deficiente de saúde e educação. As dificuldades eram muitas e todo mundo sonhava com estrada na porta. Houve um avanço muito grande em pouco tempo. Nada oficial, mas pela quilometragem de minha moto são $93 \mathrm{~km}$ de Ramais hoje trafegáveis na região do Assentamento. Hoje o Canoas é assim: muitos ramais (Figura 08), quase todos com energia elétrica; bem assistido com saúde, escola e transporte de produção. Mas, produção de agricultura familiar quase não tem mais. O rumo da história mudou, pois ao invés de plantarem bananas ou criarem galinhas, porcos ou carneiros é melhor derrubar uma árvore que dá em média 8 a $10 \mathrm{~m}^{3}$ de madeira que é vendido, hoje, oito de abril de 2010, a 160 reais o metro, resultado: é mais lucrativo mexer com madeira. Mas não é apenas este o fato da Agricultura não dar certo. No Assentamento os que têm mais recursos estão comprando os lotes e os agricultores estão virando caseiros. Grandes fazendeiros estão comprando vários lotes e anexando uns aos outros e formando grandes fazendas para criação de bovinos. O meu ramal como se pode ver no mapa é de apenas 1.100 metros, eu já perdi quatro vizinhos, pois um único fazendeiro comprou quatro lotes e formou uma fazenda com mais de 300 bois e mantém apenas um vaqueiro tomando conta, na qual não produz nada além de boi. No Assentamento, hoje, também é produzido mais de "cinco mil portas" por mês e mais aduelas e kits para estofados. São muitas as famílias vivendo exclusivamente de madeira, e $90 \%$ é madeira ilegal. Instalaram-se na vila várias "movelarias" que produzem portas em escala industrial. Uma em que eu trabalhei, consome em média $400 \mathrm{~m}^{3} / \mathrm{mês}$. Com a facilidade do dinheiro circulando vieram os problemas sociais: drogas é o carro forte, seguido de prostituição (principalmente infantil), bebidas e até latrocínio. Queda brusca na produção agrícola e aumento muito grande na extração de madeira, do desmatamento para pastagem, aumento da marginalidade e empobrecimento em curto prazo do assentamento. 


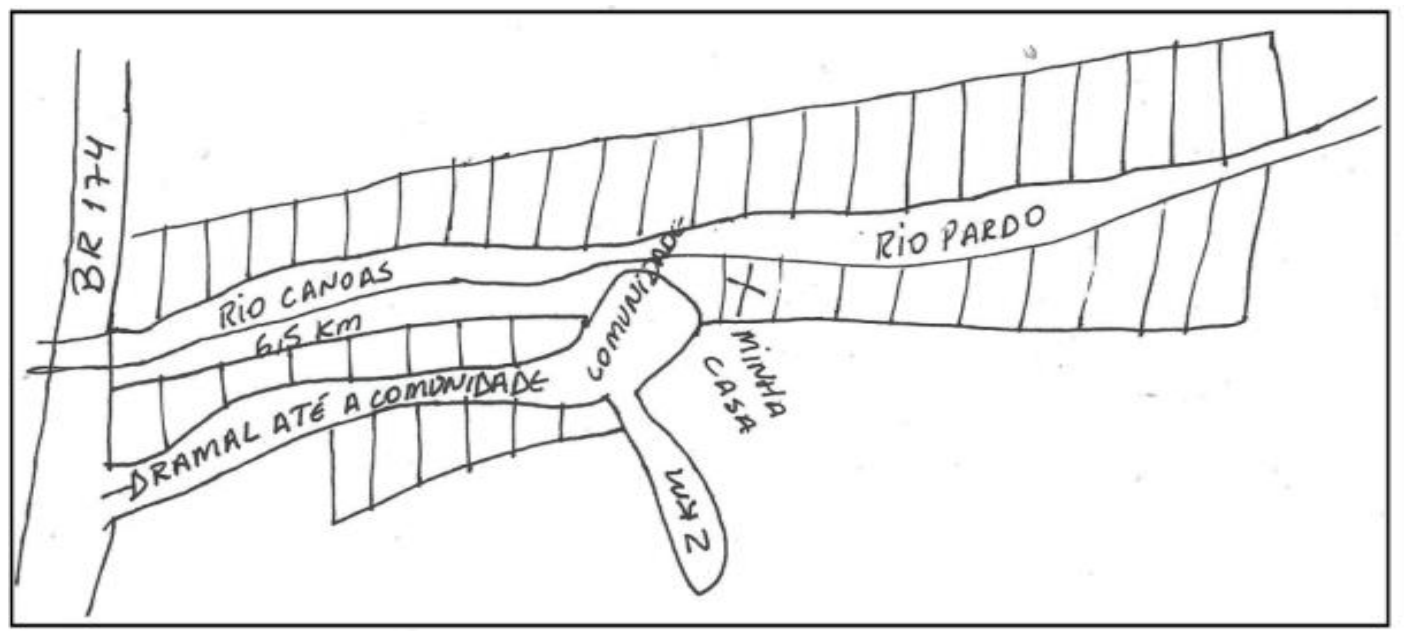

Figura 07: O Projeto de Assentamento Canoas. Fonte: Migrante Assentado 01, abril/2010

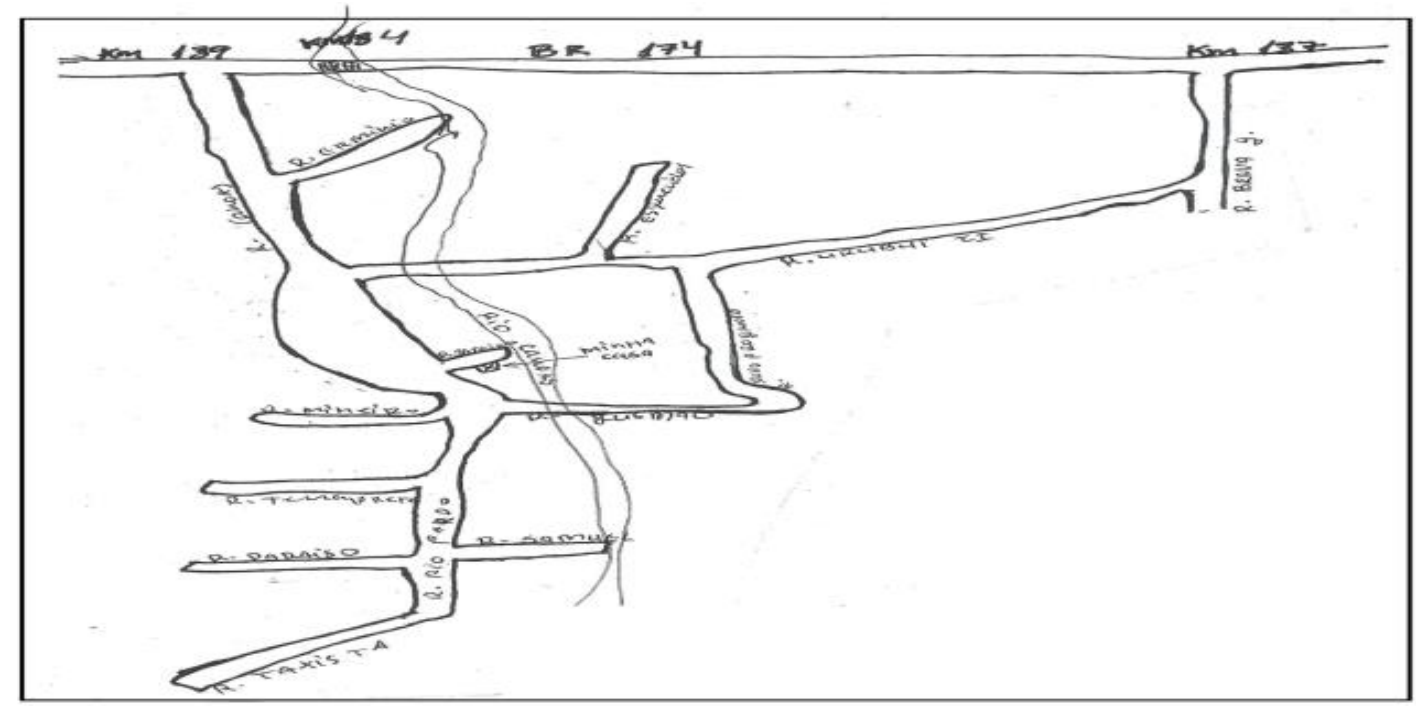

Figura 08: O Canoas atual. Fonte: Migrante Assentado 01, abril de 2010

\section{Migrante Assentado 02}

O meu objetivo aqui dentro é simplesmente anunciar o evangelho e passar para às pessoas o que eu recebi. Agente só quer passar para as pessoas aquilo que é bom, eu pelo menos sou assim. Hoje não sei se permaneço, ou não, no Assentamento. E a própria Bíblia diz que agente não sabe de onde vem nem para onde vai. Aqui é o lugar que eu amo, porque eu ajudei a desenvolvê-lo (figuras 09 e 10). Eu não criei, mas faço parte disso aqui. Querem que eu seja um produtor rural, mas os assentados não têm apoio do INCRA. E é a política que os impossibilita de trabalhar para preservar o meio ambiente, é o desenvolvimento sustentável, mas no Canoas esse desenvolvimento não chegou. Que é o que realmente a Comunidade precisaria para que tivesse um meio de vida melhor, um conforto melhor, tivesse o mínimo necessário para sobreviver.Quando eu fui assentado os técnicos do INCRA deixaram claro que o assentamento era para a agricultura de subsistência. Mas até para a agricultura de 
subsistência existe o mínimo, e, muitas vezes nem esse mínimo tem chegado. Isso não é uma crítica. É somente o que eu vejo. O lugar é constituído de um povo carente. Mas, mesmo com todas as dificuldades eu sou feliz aqui. Eu não me sinto mais um novo baiano, hoje eu me sinto livre porque eu faço o que eu gosto. Quando não estou no evangelho, to batendo meu sítio, pego o caniço vou ao igarapé pegar um peixinho, vou fazer uma farinha quando o vizinho me chama, eu acho gostoso, eu acho bom. Planto uma macaxeira para os meninos comerem, planto uma banana. Agente toma uma água de coco. Quando o negócio aperta mesmo, a gente tira açaí para vender ou para tomar.

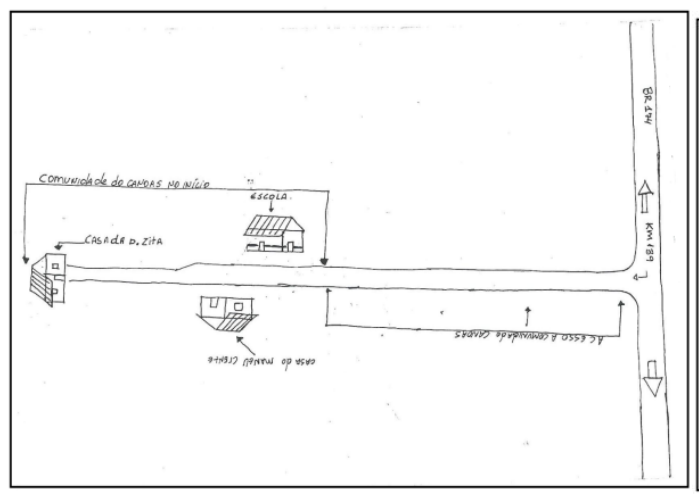

Fig.09: O Projeto de Assentamento. Fonte: Migrante Assentado 02, abril/2010.

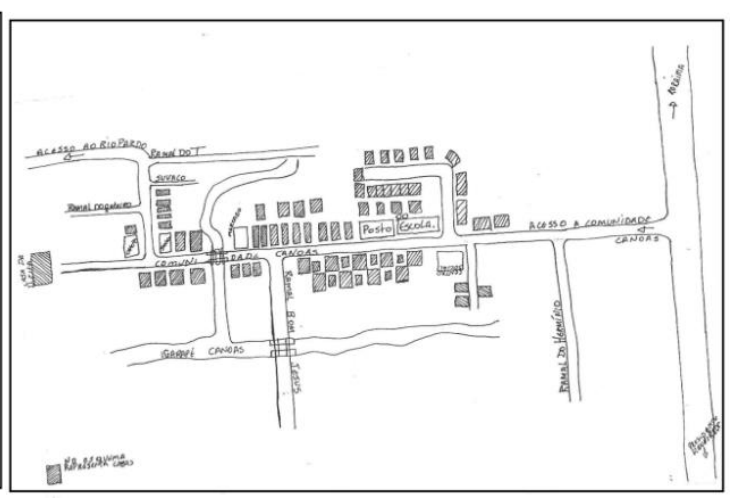

Fig.10: O Canoas atual.

Fonte: Migrante Assentado 02, abril/2010.

\section{Migrantes Assentados 05 e 06}

Os Migrantes Assentados 05 e 06 são casados. Passaram muita dificuldade quando chegaram. Ela afirma que,

Mesmo assim, sentia uma alegria tão grande, tão grande, inexplicável. Nós dois trabalhávamos muito. Eu cuidava das crianças e dos afazeres domésticos. Quando davam seis horas da tarde, ele ainda estava encoivarando, e, eu limpando ao redor da casinha. Bom, como ainda não tinha plantação, os vizinhos nos davam banana, macaxeira e batata. [...] Ele Plantou arroz, porque maranhense gosta de arroz demais, plantou milho e banana. Trabalhava de domingo a domingo, sol e chuva, dia e noite, trabalhava para ele e para os outros. E foi assim que começou. Eu gosto demais daqui. Se dependesse de mim eu não tinha nem nascido, nem me criado lá no nordeste. Lá as mulheres trabalham de mais, é no roçado, é quebrado côco babaçu, é cuidando dos filhos, tem que deixar comida no roçado para o esposo.Nunca veio na minha mente voltar para o Maranhão. Lá qualquer pedacinho de terra é caro demais, lá é só fazendeiro mesmo, e aqui não. Cultivamos coco, cupuaçu, temos um bananalzinho, a criação de gado que é muito difícil, diferente do Maranhão. Também é muito difícil o plantio de milho, de arroz, feijão, que não dá como lá no nordeste. Não é dizer que a terra não dá, porque dá, mas mais fraco. No que diz respeito ao acesso à educação, aqui no Canoas tudo é mais fácil, tem até colégio para os meus filhos estudarem, lá no Maranhão, não 


\section{些}

Ele relembra,

Quando chegamos, os moradores aqui faziam multirão, hoje é cada um por si. No Nordeste é assim: eu estou com o roçado cheio de arroz, maduro, estou doente, o que acontece: reúne um grupo de homens, de acordo com o tamanho da roça e vão cortar o arroz e pôr no paiol. No Nordeste, você planta uma lata de arroz, tu apanhas vinte alqueires de arroz, o que significa doze sacas de arroz limpo. O Amazonas é um lugar muito bom de sobreviver, mas o agricultor vive aqui de teimoso, porque tu plantas, mas se não tiver adubo, não dá. Aqui no Amazonas não é lugar de agricultor viver, vive porque é a profissão que tem. Daqui só saio para a "Glória com o Senhor".

\section{Migrante Assentada 10}

Evoluiu muito pouco, o Canoas quando eu cheguei era melhor. Não tinha essa baderna que tem hoje. Na vila tinha o colégio, algumas casinhas, poucos comércios, hoje não. Não tinha o movimento que tem hoje, carro para lá, carro pra cá, entra e sai toda hora, não tinha. O ramal do Bom Jesus era vareda, era picada. Sabe por que eu gosto desse lugar? É porque de lá de onde eu vim, eu passei por muita dificuldade. Aqui para você viajar, fazer um tratamento, tudo é mais fácil. Aqui o que você produz você vende, agora é ruim porque a terra não produz bem, precisa de adubo. Porque lá onde agente morava, tudo que agente plantava dava, mas era difícil de vender. Lá era um lamaçal no inverno, se você não encontrasse um filho de Deus que tivesse um bom coração, você passava dois, três dias sem tomar café, porque não tinha açúcar. Aqui não, aqui pode está chovendo do jeito que for, você pega uma carona até a vila, da vila pega outra para a BR e de lá pega o ônibus para Figueiredo. No Pará quando chega o inverno para tudo, aqui não tem isso. Eu acho bom aqui.

\section{O Canoas nos mapas mentais}

Nos mapas mentais temos informações que nos levam a pensar a relação estabelecida entre os habitantes e as características físicas. Para o habitante 020 Canoas é representado antes da criação da P.A. por algumas famílias e a floresta que se destacava na paisagem. Hoje a paisagem é representada com a inserção de novas famílias, o desmatamento a abertura dos ramais. Para os que chegaram a representação gráfica é demonstrada através das poucas famílias que viviam na vila e um grande vazio representado pelo espaço em branco, que seria a floresta. O P.A. para a maioria dos migrantes assentados referia-se a um espaço a ser explorado, um depósito de lotes a serem distribuídos, como foi observado na figura 07, e, a partir da atividade humana herdar uma forma, possibilitando-o características concretas com a inserção de novos elementos. Percebem e representam o lugar de maneira diferenciada, mas concordam em um ponto, o P.A é um sonho realizado, é o acesso á propriedade da terra.

Em seus depoimentos descrevem as relações estabelecidas com o ambiente físico e humano. Enfatizam a tranqüilidade, a segurança, o ar puro. Fazem comparações entre o clima e os modos de vida da cidade e do campo. Expressam satisfação em terem chegado ao lugar. Um "lugar revelado", que apesar das dificuldades oferece condições 


\section{没}

para atender ás necessidades básicas do ser humano, como: alimentação, moradia, educação e saúde.

Não se pode negligenciar as dificuldades enfrentadas, porém, em um lugar vivenciase tanto experiências topofílicas quanto topofóbicas, e, é na manifestação dessas relações que o lugar acontece. A identidade de um lugar é um processo em transformação que pode ser melhor compreendido através da " forma como nossas experiências dos lugares ocorre e seus componentes" (RELPH apud MARANDOLA Jr, 2010 p.3). Nessas experienciações os indivíduos, mesmo com vivências comuns, percebem e representam o mundo de modo diferenciado, conforme os elementos que se destacam tanto de maneira positiva quanto negativa. Essa dinamicidade possibilita ao lugar a construção e reconstrução de sua identidade, ganhando ou perdendo elementos sociais e culturais. Assim, no encontro do novo e do já estabelecido o lugar se transforma e se ressignifica. E este lugar é reconstruído através das manifestações das relações que se estabelecem entre os indivíduos que o vivenciam, e que, portanto, compartilham e assimilam hábitos, costumes, crenças e convicções com os que chegam, garantindo ao lugar, sua identidade e autenticidade.

\section{CONCLUSÃO}

A realização desta pesquisa possibilitou a reflexão sobre o processo de reconstrução do lugar através da percepção e representação nas multidimensionalidades do vivido pelos indivíduos que fazem parte de sua dinâmica. A partir da compreensão do entrelaçamento das relações que vão se estabelecendo nos deferentes períodos que o formam, apreende-se como um espaço indiferenciado vai se tornando parte do mundo vivido, o lugar. As experiências vivenciadas nem sempre são carregadas de sentimentos topofílicos. A dinâmica de um lugar acontece em diferentes contextos, podendo ser agradáveis, ou não. A fenomenologia buscou compreender a percepção e a representação das vivências. Toma o corpo não como objeto, mas como sujeito, pois é através dele que o mundo é experienciado (MERLEAU-PONTY, 2006) . Através do corpo, mente, emoção e vontade o ser interage com o mundo e constrói um mosaico de lugares especiais com os quais possui suas identidades. Os habitantes dos lugares os terão na memória onde se desenvolveram suas intersubjetividades.

Os mapas mentais e as narrativas na perspectiva da história oral de vida, tomados como procedimentos metodológicos, possibilitou um retorno aos fenômenos em si, às manifestações do mundo vivido, presentes na consciência geográfica imediata de cada sujeito. Entre si, mapas mentais e narrativas estão relacionados, o que permite conhecer os elementos mais significativos na trajetória dos migrantes assentados, dentro da abordagem fenomenológica da Geografia Humanística. A abordagem teórico-metodológica, a leitura do trajeto, das vivências e da própria re- construção do lugar, conduz à reflexão sobre o significado da migração, e, sua implicação na dinâmica do mundo vivido.

Portanto, no acesso ao mundo vivido de cada indivíduo, o diálogo foi conduzido pelo pensar o LUGAR como uma (re) construção dinâmica que acontece tendo como base as relações estabelecidas entre os sujeitos, e, destes com os elementos físicos que o 
constituem. A MIGRAÇÃO ficou compreendida como um fenômeno que influenciou na dinâmica do lugar, através da inserção de outras características culturais, (re) significando-o. E a IDENTIDADE, um elo que conduziu o fenômeno da MIGRAÇÃO em um determinado espaço que se transformou em lugar, a partir das manifestações estabelecidas nas relações de identidade, que se (re) construíram e se (re) constroem através da identificação, possibilitando a cada sujeito o sentimento de pertencimento, ou não, ao longo do tempo.

\section{REFERÊNCIAS BIBLIOGRÁFICAS}

BECKER, O. M. S. Mobilidade espacial da população:conceitos, tipologias, contextos.In: CASTRO, I. E. et al. (orgs). Explorações Geográficas: percursos no fim do século. Rio de Janeiro: Bertrand Brasil, 1997.

BEZERRA JR, B. A solidão de não pertencer: uma observação a partir de um fragmento de Clarice Lispector. In: NETO, H. P.; FERREIRA, A. P. (Orgs). Cruzando Fronteiras Disciplinares: Um panorama dos estudos migratórios. Rio de Janeiro: Revan, 2005.

BUTTIMER, A. Apreendendo o dinamismo do mundo vivido. In: CHRISTOFOLETTI, A. Perspectivas da geografia. São Paulo: Difel, 1985.

CLAVAL, P. O papel da nova geografia cultural na compreensão da ação humana. In: In: CORREAA, R. L.; ROSENDAHL, Z (Orgs). Matrizes da Geografia Cultural. Rio de janeiro: EDUERJ, 2001. pp. 35 - 86.

HAESBAERT, R. Identidades territoriais. IN: ROZENDHAL, Z.; CORREAA, R. L. Manifestações da Cultura no Espaço. Rio de janeiro: EDUERJ, 1999.

INCRA. Instituto nacional de Colonização e Reforma Agrária. Manaus/AM, 2009.

LENCIONE, S. Região e Geografia. São Paulo: USP, 1999.

MARANDOLA JR. E. Identidade e autenticidade dos lugares: O Pensamento de Heidegger em Place end placelessness, de Edward Relph. In: XIV Encontro Nacional de Geógrafos, 2010, Porto Alegre/RG. Anais. Porto Alegre: URGS, 2010. P 1-9.

MEIHY, J. C. S. B. Manual de História Oral. São Paulo: Loyola, 2005.

MELLO, J. B. F. de. Descortinando e ((re) pensando categorias espaciais com base na obra de Yi-Fu Tuan. In: ROSENDHAL, Z; CORRÊA, R. L. Matrizes da Geografia Cultural. Rio de Janeiro: Edurj, 2001.

MENEZES, F. L. Migração: Uma Perspectiva Psicológica, Uma Leitura Pós-Moderna ou, Simplesmente, Uma Visão Preconceituosa. In: CUNHA, M. J.C. [et al.]. Migração e Identidade: olhares sobre o tema. São Paulo: Centauro, 2007. 
NOGUEIRA, A. R. B. Percepção e Representação Geográfica: A “Geograficidade dos mapas mentais dos comandantes de embarcações no Amazonas.Tese de Doutorado. USP. Departamento de Geografia da Faculdade de Filosofia, Letras e Ciências Humanas. 2001.

NOGUEIRA, A. R. B. Uma Interpretação Fenomenológica na Geografia. In: SILVA, A. A. D. da; GALENO, A. (Orgs.) Geografia: ciência do complexus: ensaios transdisciplinares. Porto Alegre: Sulina, 2004, pág. 209-236.

OLIVEIRA, P. R. M de. O migrante, seu drama psíquico e a percepção das diferenças. In: NETO, H. P.; FERREIRA, A. P. (Orgs). Cruzando Fronteiras Disciplinares: Um panorama dos estudos migratórios. Rio de Janeiro: Revan, 2005.

RELPH, E. As Bases Fenomenológicas da Geografia. In: Geografia. 4(7): Rio Claro - SP. Abril 1979, pág: 1 - 25.

SILVA, G. A. da. O Assentamento como forma de Ocupação em Presidente Figueiredo: Projeto de Assentamento Canoas. Manaus: Ufam, Monografia, Especialização em Geografia da Amazônia Brasileira. Departamento de Geografia, Universidade Federal do Amazonas, 2005.

SINGER, P. Migrações Internas: considerações teóricas sobre o seu estudo. In: Economia Política da Urbanização. 14 ed. São Paulo: contexto, 1998. Pp. 29-62.

SOUZA, R. L. de. Projetos de Assentamento na Amazônia: Condições socioeconômicas e Demográficas: O caso do Assentamento Canoas. Manaus: Ufam, Monografia, Curso de Ciências Econômicas. Faculdade de Estudos Sociais. Departamento de Econômia e Análise, Universidade Federal do Amazonas, 2007.

TUAN, Y. Topofilia: um estudo da percepção, atitudes e valores do meio ambiente. Tradução: Lívia de Oliveira. São Paulo/Rio de Janeiro: Difel, 1980.

TUAN, Y. Espaço e Lugar: a perspectiva da experiência. Tradução: Lívia de Oliveira. São Paulo: Difel, 1983.

Submetido em:21/08/2017 Aceito para publicação em:13/03/2018 